\title{
Risk of hepatitis B virus transmission by diagnostic hysteroscopy
}

N.C. Santos ${ }^{2}$, J.R.R. Pinho', M.F. Lemos' ${ }^{1}$, R.C. Moreira ${ }^{1}$, C.M.C. Lopes², M.T.J. Sacilotto ${ }^{2}$, M. Tacla ${ }^{2}$, W.S. Pinheiro ${ }^{2}$ and L.O. Ramos ${ }^{2}$
${ }^{1}$ Serviço de Virologia, Instituto Adolfo Lutz, São Paulo, SP, Brasil ${ }^{2}$ Departamento de Ginecologia, Hospital das Clínicas, Faculdade de Medicina, Universidade de São Paulo, São Paulo, SP, Brasil
Correspondence

J.R.R. Pinho

Instituto Adolfo Lutz

Av. Dr. Arnaldo, 355

01246-902 São Paulo, SP

Brasil

Fax: $+55-11-3085-3505$

E-mail: jrrpinho@usp.br

Research supported by FAPESP (No. 97/01190-3).

Received October 23, 2002 Accepted November 27, 2003

\section{Abstract}

Few data are available in the literature concerning the efficacy of standard hysteroscope disinfection procedures to prevent hepatitis B transmission. The aim of the present study was to determine the risk of hepatitis B virus (HBV) transmission during hysteroscopy among anti-HBc-seropositive women. Serum and hysteroscopic samples were collected from 62 women after diagnostic hysteroscopy. All samples were tested for serologic HBV markers. Polymerase chain reactions (PCR) were carried out to amplify regions $\mathrm{C}$ and $\mathrm{S}$ of the viral genome and only samples amplified by both pairs of primers were considered to be positive. Anti-HBc was repeatedly reactive in $48(77 \%)$ of 62 serum samples, and HBsAg was detected in $8(13 \%)$. At least one HBV serologic marker was found in $49(79 \%)$ samples. Only one sample was HBsAg positive and anti-HBc negative. HBV-DNA was detected by PCR in 7 serum samples but in only 3 hysteroscopic samples obtained just after hysteroscopy. It is noteworthy that high levels of anti-HBc IgM were detected in one HBsAg-negative patient who showed an HBV-DNA-positive hysteroscopic sample. An elevated sample/cut-off ratio for anti-HBc IgM suggests recent infection and reinforces the need for testing for $\mathrm{HBsAg}$ and anti-HBc before hysteroscopy, since acute hepatitis B can be clinically asymptomatic. Viral DNA was not detected in any hysteroscopic samples collected after washing and disinfecting procedures with glutaraldehyde. We conclude that HBV-DNA can be found in the hysteroscope soon after hysteroscopy, but standard disinfecting procedures are effective in viral removal.

\section{Introduction}

In 1995, the European Society for Gynecologic Endoscopy suggested at their Rome meeting that, from then on, all specialists should require serologic tests for hepatitis B and $\mathrm{C}$ for any women undergoing endoscopic based on the fact that the standard proceprocedures (1). This recommendation was
Key words - Hepatitis B

- Hysteroscopy

- Disinfection

- Polymerase chain reaction dures of endoscope disinfection (soap, water and $2 \%$ glutaraldehyde) were not adequate for complete sterilization, with a potential risk for transmission of these diseases during endoscopy and hysteroscopy (2). However, this recommendation has been criticized since it would increase costs without bringing benefits to the patients since the risk of contamination through endoscopes is low (3). 
The potential risk for patient-to-surgeon contamination with hepatitis B virus (HBV) during transurethral resection has been previously reported, leading to the recommendation of previous vaccination of the surgical staff (4). Other studies have revealed that most professionals are careless in protecting themselves and their patients from the risk of HBV contamination (5). Prevention measures should be applied to those working with hysteroscopy and special procedures should be applied to avoid patient-to-patient infection. Surprisingly, no reports on patient-topatient HBV infection after hysteroscopy are available.

Axon (6) recommended mechanical washing of the endoscopes followed by immersion in $2 \%$ glutaraldehyde for 5 to 10 min as well as previous hepatitis B vaccination to ensure patient protection. Rutala et al. (7) reported a wide variety in the methods for disinfecting endoscopes, with $91 \%$ of the professional staff using different immersion times in $2 \%$ glutaraldehyde. Besides, in 58\% of the hospitals, endoscopes were also treated with ethylene oxide if they had been used in patients infected with human immunodeficiency virus (HIV), HBV or Mycobacterium tuberculosis.

Finally, in a review of the literature related to instrument management, we were unable to find any reference regarding special procedures for disinfection of hysteroscopes. In view of these controversial guidelines and the absence of data on the potential transmission of HBV by hysteroscopy, the objective of the present study was to investigate the real risk of hepatitis B transmission during diagnostic hysteroscopy.

\section{Patients and Methods}

\section{Patients}

From September 1995 to May 1999, 1410 outpatients were submitted to diagnostic hysteroscopy at the Gynecology outpatient clinic of the Medical School Hospital of the University of São Paulo. These patients had been previously screened as seropositive for total anti-HBc antibodies (raised against the core antigen of $\mathrm{HBV}$ ) at the central hospital laboratory. During this period, 62 (4.39\%) women had a positive anti-HBc result and were selected for the present study.

The study protocol was submitted to and approved by the Ethics Committee of the Adolfo Lutz Institute and Medical School Hospital of the University of São Paulo, and informed consent was obtained from each patient.

\section{Hysteroscope disinfection procedures}

Hysteroscopes were extensively washed with soap and running water, immersed for 10 min in a $2 \%$ glutaraldehyde solution, and rinsed with distilled water after each hysteroscopy. They were then treated for $8 \mathrm{~h}$ in a chamber with ethylene oxide and for $24 \mathrm{~h}$ in a forced ventilation room with 25 air changes per hour.

\section{Samples}

Ten milliliters of blood was collected from 62 patients into dry tubes and $5 \mathrm{ml}$ of blood was collected into EDTA-containing tubes from 30 patients. Three samples from the hysteroscopes used for each of the 62 patients were collected as described below.

\section{Sample collection and storage}

Serum. Blood samples were sent to the Adolfo Lutz Institute on the day of collection. Serum was separated by centrifugation within a maximum of $2 \mathrm{~h}$ after collection and three aliquots were added to three labeled tubes: one stored at $4^{\circ} \mathrm{C}$ for serologic tests, one stored at $-20^{\circ} \mathrm{C}$ for the polymerase chain reaction (PCR), and the third one was stored at $-20^{\circ} \mathrm{C}$ in case further confirmatory tests were needed. 


\section{Hysteroscope}

Three samples were collected from the hysteroscopes: one just before use (after sterilization with ethylene oxide - O), another immediately after hysteroscopy $(\mathrm{H})$, and the third after routine washing and disinfection procedures (W). These samples were identified with the patient's number and respectively labeled as $\mathrm{O}, \mathrm{H}$ and $\mathrm{W}$.

Strips of Whatman 3MM CHR paper (Whatman, Kent, UK) of about $3 \mathrm{~cm}^{2}$, previously autoclaved, were wiped across the entire hysteroscope surface and added to $15-\mathrm{ml}$ dry polypropylene flasks. On the same day, the strips were cut into two halves using new and sterilized surgical blades and stored in other polypropylene flasks at $-20^{\circ} \mathrm{C}$ for further analysis.

\section{Whole blood}

Blood samples were collected into EDTA tubes and, within a maximum of $2 \mathrm{~h}, 50-\mu 1$ aliquots were added to sterile Whatman $3 \mathrm{MM}$ CHR paper strips of approximately $3 \mathrm{~cm}^{2}$, air-dried and stored at $-20^{\circ} \mathrm{C}$. These samples were used for standardization of the techniques for HBV-DNA extraction from samples containing whole blood dried on filter papers, such as those obtained just after hysteroscopy $(\mathrm{H})$, as described below.

\section{Serologic reactions}

Serologic testing was first performed on the 62 samples for $\mathrm{HBsAg}$, anti-HBc and anti-HBs. In 49 cases in which at least one positive marker was found, the presence of the following serologic markers was also determined: anti-HBc IgM class, $\mathrm{HBeAg}$, and anti-HBe. Samples with indeterminate results, i.e., a signal between 0.9 to 1.1 times the cut-off value, were subjected to further duplicate testing. Anti-HBc IgM results were also expressed as sample/cut-off (S/CO) ratios. All tests were carried out with commer- cially available ELISA kits.

\section{Sample preparation for PCR}

Serum samples were denatured with $\mathrm{NaOH}$ and neutralized with $\mathrm{HCl}$ prior to PCR. The protocol for DNA extraction from filter paper was standardized using strips of sterile paper containing serum or whole blood from patients known to be HBV-DNA positive by PCR amplification from serum samples, as described below.

A piece of Whatman paper of approximately $0.5 \mathrm{~cm}^{2}$ was placed inside a polypropylene microtube and submitted to proteinase $\mathrm{K}$ digestion followed by phenol-chloroform extraction (8). After ethanol precipitation, the pellet was resuspended in $15 \mu \mathrm{l}$ of Milli Q water. A final incubation was carried out at $96^{\circ} \mathrm{C}$ for $15 \mathrm{~min}$ or 1 to $2 \mathrm{~h}$ in samples showing evidence of PCR inhibition detected by non-amplification of the $\beta$-globin gene (see below), with an additional centrifugation at $16,060 \mathrm{~g}$ at $0^{\circ} \mathrm{C}$ for 3 min just before starting the PCR amplification.

\section{Polymerase chain reaction}

Samples were first assayed by nested PCR using the methodology described by Kaneko et al. (9), with slight modifications. This method amplifies a fragment of the HBV C gene that codes for the core antigen and has a sensitivity threshold of $3 \mathrm{HBV}$ genomic copies.

Outer primers 1763 and 2032R and inner primers 1778-E and 2017R-B were used in the first and second round of amplification, respectively. All 62 serum samples and all $\mathrm{O}$ and $\mathrm{H}$ hysteroscopic samples were analyzed by this method. The only $\mathrm{W}$ samples analyzed were those from patients with a positive PCR result for $\mathrm{O}$ or $\mathrm{H}$ samples.

Samples found to be positive with these primers were then amplified by nested PCR using outer primers HBS1F and HBS1R and inner primers $\mathrm{HBS} 2 \mathrm{~F}$ and $\mathrm{HBS} 2 \mathrm{R}$, driven to 
amplify a fragment of the S gene, which codes for the viral surface antigen (10).

We considered as positive only the samples that were amplified by PCR with both pairs of primers. The primer positions in the HBV genome (strain HBVADW, GenBank Access Number X00715) were: HBS $1 F$ (244-267), HBS2F (255-278), HBS2R (648-671), HBS1R (668-691), 1763 (1891-1920), 1778-E (1906-1926), 2017RB (2125-2154), and 2032R (2131-2160).

To test for the presence of PCR inhibitors, PCR-negative hysteroscopic samples from women known to be HBV-DNA positive were also amplified using primers specific for the human ß-globin gene (11).

All reagents were purchased from Life Technologies do Brasil (São Paulo, SP, Brazil).

\section{Results}

The serologic results for the hepatitis B markers are shown in Table 1. At least one HBV serologic marker was found in $49(79 \%)$ samples. Only one sample was HBsAg positive and anti-HBc negative. Nine patients were positive for total anti-HBc and negative for either HBsAg or anti-HBs. Of these, only 4 were positive for anti-HBe and the other 5 presented anti-HBc as the only detectable marker related to $\mathrm{HBV}$.

One anti-HBc IgM-positive sample (S/

Table 1. Serologic data for the hepatitis B markers.

\begin{tabular}{lcccc}
\hline & \multicolumn{3}{c}{ Serology } \\
\cline { 2 - 5 } & $\begin{array}{c}\text { Reactive } \\
\mathrm{N}(\%)\end{array}$ & $\begin{array}{c}\text { Non-reactive } \\
\mathrm{N}(\%)\end{array}$ & $\begin{array}{c}\text { Indeterminate } \\
\mathrm{N}(\%)\end{array}$ & $\begin{array}{c}\text { Total } \\
\mathrm{N}(\%)\end{array}$ \\
\hline HBsAg & $8(13)$ & $54(87)$ & $0(0)$ & $62(100)$ \\
Total anti-HBc & $48(77)$ & $13(21)$ & $1(2)$ & $62(100)$ \\
Anti-HBs & $32(52)$ & $29(47)$ & $1(2)$ & $62(100)$ \\
Anti-HBc IgM & $5(10)$ & $44(90)$ & $0(0)$ & $49(100)$ \\
Anti-HBe & $32(65)$ & $17(35)$ & $0(0)$ & $49(100)$ \\
HBeAg & $0(0)$ & $49(100)$ & $0(0)$ & $49(100)$ \\
\hline
\end{tabular}

Only samples positive for $\mathrm{HBsAg}$ and/or total anti-HBc were assayed for the other markers.
$\mathrm{CO}$ ratio $=6.21)$ was HBsAg negative. Interestingly, as shown below, the $\mathrm{H}$ sample obtained from this patient was HBV-DNA positive. The other 4 anti-HBc IgM-positive samples $(\mathrm{S} / \mathrm{CO}$ ratios ranging from 1.4 to 14.52) were all HBsAg negative and 3 of them were also anti-HBs positive.

PCR for the HBV $\mathrm{C}$ region was performed in all serum samples, 7 of which (11.29\%) were positive. These positive results were confirmed by PCR amplification of the HBV S region.

Only hysteroscopic samples from patients with detectable DNA by PCR in serum were also analyzed by PCR. A summary of the serologic and PCR results for these patients is shown in Table 2.

PCR-positive results were obtained from $3 \mathrm{H}$ samples. Two patients were positive for $\mathrm{HBsAg}$, total anti-HBc, anti-HBe and HBVDNA, one of them was also positive for anti$\mathrm{HBc} \operatorname{IgM}(\mathrm{S} / \mathrm{CO}$ ratio $=14.52)$. Another sample was from a patient positive for total anti-HBc, anti-HBc IgM $(\mathrm{S} / \mathrm{CO}$ ratio $=6.21)$, anti-HBs, anti-HBe, but negative for $\mathrm{HBsAg}$ and serum HBV-DNA. No W sample from patients with detectable HBV-DNA in sample $\mathrm{H}$ was positive by PCR.

Among the 5 PCR-negative paper samples identified as $\mathrm{H}$ from patients with PCRpositive serum, 4 were positive for the human $\beta$-globin gene.

\section{Discussion}

A study of serologic HBV markers was carried out to assess their utility for patient screening and to search for other markers. Initially, the serologic tests for anti-HBc that had been previously performed in the hospital central laboratory were repeated. Of the 62 allegedly positive samples, $48(77.42 \%)$ were confirmed to be anti-HBc positive, one $(1.61 \%)$ was indeterminate, and the remaining $13(20.97 \%)$ were negative. Only $77.42 \%$ samples with a previous anti-HBc positive test were repeatedly reactive, reinforcing the 
need to confirm a positive result by retesting another sample, since ELISA anti-HBc tests are known to be prone to yielding falsepositive results (12).

Only $5(8.06 \%)$ of the 62 patients presented a result that was positive only for anti$\mathrm{HBc}$ and negative for all other HBV markers. Among the 48 anti-HBc-positive patients, $31(64.58 \%)$ were also anti-HBs positive. As the latter is considered a marker of immunity for hepatitis B, in theory, this group of patients does not offer a risk of transmission. On the other hand, 7 of these patients had also detectable HBsAg levels and could potentially transmit hepatitis $B$. None of them had detectable HBeAg and all were serologically anti-HBe positive.

$\mathrm{HBeAg}$-positive patients are more likely to transmit hepatitis $\mathrm{B}$, and their absence in the present study must have decreased the possibility of transmission through hysteroscopy. Anti-HBe-positive patients tend to have lower titers of circulating virus $(13,14)$. Nevertheless, these women could potentially transmit hepatitis B (15). There is always the possibility of infection with pre-core mutants (unable to produce $\mathrm{HBe} \mathrm{Ag}$ ) that have been associated by some investigators with more severe clinical hepatitis (16).

It is noteworthy that high levels of anti-
$\mathrm{HBc}$ IgM were detected in one HBsAg-negative patient who showed an HBV-DNA-positive $\mathrm{H}$ sample. An elevated $\mathrm{S} / \mathrm{CO}$ ratio for anti-HBc IgM suggests recent infection and reinforces the need for testing for HBsAg and anti-HBc before hysteroscopy, since acute hepatitis B can be clinically asymptomatic (17).

The most sensitive marker for predicting the potential of an instrument to transmit hepatitis B is the detection of viral DNA by PCR. However, PCR is a higly sensitive technique and false-positive results due to contamination with amplified products may arise. Although we cannot rule out this possibility, in this study we followed strict procedures to avoid cross-contamination (18). The use of more than one pair of primers has been previously adopted to assure the reliability of PCR results, preventing false-positive results due to cross-contamination (19). In our study, a PCR result was considered positive only when both the HBV C and S regions were amplified.

The present study showed that the methodology employed for disinfecting the hysteroscopes was adequate and effective for HBV elimination. No sample from hysteroscopes treated with ethylene oxide was positive, attesting to the efficacy of this

\begin{tabular}{|c|c|c|c|c|c|c|c|c|c|c|c|}
\hline & \multicolumn{6}{|c|}{ Enzyme immunoassay } & \multicolumn{4}{|c|}{ HBV-DNA by PCR } & \multirow{3}{*}{$\begin{array}{c}\begin{array}{c}\text { B-Globin gene } \\
\text { by PCR }\end{array} \\
\begin{array}{c}\text { Hysteroscopic } \\
\text { H }\end{array}\end{array}$} \\
\hline & \multirow[t]{2}{*}{ HBsAg } & \multirow{2}{*}{$\begin{array}{l}\text { Anti- } \\
\text { HBC }\end{array}$} & \multirow{2}{*}{$\begin{array}{c}\text { Anti- } \\
\text { HBc IgM }\end{array}$} & \multirow{2}{*}{$\begin{array}{l}\text { Anti- } \\
\text { HBs }\end{array}$} & \multirow{2}{*}{$\begin{array}{l}\text { Anti- } \\
\mathrm{HBe}\end{array}$} & \multirow[t]{2}{*}{$\mathrm{HBeAg}$} & \multirow[t]{2}{*}{ Serum } & \multicolumn{3}{|c|}{ Hysteroscopic } & \\
\hline & & & & & & & & $\mathrm{O}$ & $\mathrm{H}$ & W & \\
\hline 1 & + & + & - & - & + & - & + & - & - & nd & + \\
\hline 2 & + & + & - & - & + & - & + & - & - & nd & + \\
\hline 3 & + & + & - & - & + & - & + & - & - & nd & + \\
\hline 4 & + & + & - & - & + & - & + & - & - & nd & + \\
\hline 5 & + & + & - & - & + & - & + & - & - & nd & - \\
\hline 6 & + & + & - & - & + & - & + & - & + & - & nd \\
\hline 7 & + & + & + & - & + & - & + & - & + & - & nd \\
\hline 8 & - & + & + & + & + & - & - & - & + & - & nd \\
\hline
\end{tabular}

$\mathrm{O}=$ hysteroscopic samples collected just before use, after ethylene oxide sterilization; $\mathrm{H}=$ collected immediately after hysteroscopy; $\mathrm{W}=$ collected after routine washing and disinfection procedures; $\mathrm{nd}=\mathrm{not}$ done. 
method. Seven patients were positive for viral DNA in serum. After hysteroscopy, viral DNA was detected in hysteroscopic samples in 2 of them. The third PCR-positive $\mathrm{H}$ sample had a negative PCR result in its serum counterpart, despite being anti$\mathrm{HBc}$ IgM positive $(\mathrm{S} / \mathrm{CO}$ ratio $=6.21)$. This may have been the case of a resolving acute form of hepatitis B. In such case, HBV-DNA was not detectable, possibly due to a low viral load in serum. Viral DNA would only be detectable in the lymphocytes, explaining why only the material from the hysteroscope was found to be positive (20). Unfortunately, it was not possible to obtain a new sample from this patient to confirm this hypothesis.

The washing procedure and glutaraldehyde treatment of the hysteroscopes proved to be efficient for HBV elimination since no $\mathrm{H}$ sample collected after examination of an HBVDNA-positive patient was PCR positive.

Of the 5 patients positive for PCR in serum but negative for the $\mathrm{H}$ sample, 4 presented positive amplification for the $\beta$-globin gene, indicating that there was no inhibitor in these reactions. However, it remains un- clear whether there was an inhibitor in the paper reaction or the DNA extraction from the hysteroscope was not efficient in the case without $\beta$-globin amplification.

Since the volume of blood that remains adhered to the hysteroscopes is small (ca. 19 $\mu \mathrm{l}$ assuming a $0.1-\mathrm{mm}$ thick blood film), the number of viral particles found in the instrument after use in a PCR-positive patient was small and, furthermore, the tested disinfecting procedures seem to be sufficient to inactivate the virus.

Perhaps our results would have been different if there had been HBeAg-positive patients with a higher viral load. However, patients with this serologic pattern generally have more severe hepatitis and usually do not present themselves for hysteroscopic procedures. Even so, their clinical status would be more easily detected by careful anamnesis.

The present study showed that HBV can be found in hysteroscopes soon after the examination, but the disinfecting procedure consisting of washing followed by glutaraldehyde treatment and ethylene oxide sterilization is effective for virus removal.

\section{References}

1. Mencaglia L, Tiso E, Tantini C \& Bianchi R (1996). Risks of virus transmission during diagnostic hysteroscopy. Journal of the American Association of Gynecologic Laparoscopists, 3 (Suppl): S30.

2. Deva AK, Vickery K, Zou J, West RH, Selby W, Benn RA, Harris JP \& Cossart YE (1998). Detection of persistent vegetative bacteria and amplified viral nucleic acid from in-use testing of gastrointestinal endoscopes. Journal of Hospital Infection, 39: 149-157.

3. Chiaramonte M, Farini R, Truscia D, Zampieri L, Di Mario F, Pornaro E, Vecchiati U \& Naccarato R (1983). Risk of hepatitis B virus infection following upper gastrointestinal endoscopy: a prospective study in an endemic area. Hepatogastroenterology, 30: 189-191.

4. Taylor JD (1990). AIDS and hepatitis B and C: contamination risk at transurethral resection. A study using sodium fluorescein as a marker. Medical Journal of Australia, 153: 257-260.

5. Treasure P \& Treasure ET (1994). Survey of infection control procedures in New Zealand dental practices. International Dental Journal, 44: 342-348.

6. Axon AT (1991). Disinfection of endoscopic equipment. Baillieres Clinical Gastroenterology, 5: 61-77.

7. Rutala WA, Clontz EP \& Hoffmann KK (1991). Disinfection practices for endoscopes and other semi critical items. Infection Control and
Hospital Epidemiology, 12: 282-288.

8. Sambrook J \& Russell DW (2001). Molecular Cloning. A Laboratory Manual. 3rd edn. Cold Spring Harbor Laboratory Press, Cold Spring Harbor, NY, USA.

9. Kaneko S, Feinstone SM \& Miller RH (1989). Rapid and sensitive method for the detection of serum hepatitis B virus DNA using the polymerase chain reaction technique. Journal of Clinical Microbiology, 27: 1930-1933.

10. Sitnik R, Pinho JRR, Da Silva LC, Fonseca LEP, Carrilho FJ \& Bernardini AP (2000). Hepatitis B virus genotypes and pre-core mutants in chronic hepatitis B patients from São Paulo city, Brazil. Hepatology, 32 (Part 2): 587A (Abstract).

11. Saiki RK, Scharf S, Faloona F, Mullis KB, Horn GT, Erlich HA \& Arnheim N (1985). Enzymatic amplification of beta-globin genomic sequences and restriction site analysis for diagnosis of sickle cell anemia. Science, 230: 1350-1354.

12. Lai CL, Lau JY, Yeoh EK, Chang WK \& Lin HJ (1992). Significance of isolated anti-HBc seropositivity by ELISA: implications and the role of radioimmunoassay. Journal of Medical Virology, 36: 180-183.

13. Jardi R, Buti M, Rodriguez-Frias F, Cortina M, Esteban R, Guardia J \& Pascual C (1996). The value of quantitative detection of HBV-DNA 
amplified by PCR in the study of hepatitis B infection. Journal of Hepatology, 24: 680-685.

14. Da Silva LC, Pinho JR, Sitnik R, Da Fonseca LE \& Carrilho FJ (2001). Efficacy and tolerability of long-term therapy using high lamivudine doses for the treatment of chronic hepatitis B. Journal of Gastroenterology, 36: 476-485.

15. Sinatra FR, Shah P, Weissman JY, Thomas DW, Merritt RJ \& Tong MJ (1982). Perinatal transmitted acute icteric hepatitis $B$ in infants born to hepatitis B surface antigen-positive and anti-hepatitis Bepositive carrier mothers. Pediatrics, 70: 557-559.

16. Scaglioni PP, Melegari M \& Wands JR (1997). Biologic properties of hepatitis B viral genomes with mutations in the precore promoter and precore open reading frame. Virology, 233: 374-381.
17. Lemon SM, Gates NL, Simms TE \& Bancroft WH (1981). IgM antibody to hepatitis B core antigen as a diagnostic parameter of acute infection with hepatitis B virus. Journal of Infectious Diseases, 1436: 803-809.

18. Kwok S \& Higuchi R (1989). Avoiding false positives with PCR. Nature, 339: 237-238.

19. Cacciola I, Pollicino T, Squadrito G, Cerenzia G, Orlando ME \& Raimondo $G$ (1999). Occult hepatitis B virus infection in patients with chronic hepatitis C liver disease. New England Journal of Medicine, 341: 22-26.

20. Michalak TI, Pasquinelli C, Guilhot S \& Chisari V (1994). Hepatitis B virus persistence after recovery from acute viral hepatitis. Journal of Clinical Investigation, 93: 230-239. 